\title{
Political Connection, Profitability, and Capital Intensity Against Tax Avoidance in Coal Companies on the Indonesia Stock Exchange
}

\author{
Rizki Fitri Amalia ${ }^{1 *}$ \\ ${ }^{1}$ Accounting Study Program, Polytechnic of Palcomtech, Palembang, Indonesia \\ *Corresponding author Email: rizki_fitri@palcomtech.ac.id
}

\begin{abstract}
Tax avoidance is an aggressive tax strategy carried out by companies in minimizing taxes, so that these activities will pose risks for companies, including fines and bad reputation of the company in the eyes of the public. This study aims to determine the analysis of political connections, profitability and capital intensity against tax avoidance. The population in this study were all mining companies listed on the Indonesia Stock Exchange from 2014 to 2018. Data analysis in this study would use multiple regression analysis techniques. The results of the study stated that, the Political connection influenced the practice of tax avoidance. Return on Assets influenced tax avoidance. Capital Intensity influenced tax avoidance.
\end{abstract}

Keywords: political connection, profitability, capital intensity, tax avoidance

\section{INTRODUCTION}

One of the efforts made by the company is to minimize taxes within the limits that do not violate regulations because the tax is one of the factors of profit reduction. The amount of tax depends on the amount of income. The greater the income, the greater the tax. Therefore, companies need proper tax planning so that companies pay taxes properly, correctly and efficiently. Tax avoidance is an aggressive tax strategy carried out by companies in minimizing taxes, so that these activities will pose risks for companies, including fines and bad reputation of the company in the eyes of the public. As such, many tax experts are of the opinion that Tax Avoidance does not violate taxation provisions, generally involving acts that are

The coal mining industry contributes very little tax. Data from the Ministry of Finance shows the tax ratio contributed from the mineral and coal mining sector in 2016 was only $3.9 \%$, while the national tax ratio in 2016 was $10.4 \%$. The low tax ratio cannot be separated from the problem of tax avoidance by coal industries. Tax avoidance is a practice that utilizes legal loopholes and weaknesses of the existing taxation system. Although it does not violate the law, it is morally unjustifiable. The Ministry of Finance noted that the number of taxpayers (WP) with mineral mining business licenses who did not report their annual tax return is more than the taxpayers that report. In 2015 out of 8,003 taxpayers from coal industries, there were 4,532 taxpayers who did not report their tax returns. This figure certainly did not include small-scale coal players who do not register as taxpayers. The business world is very closely related to politics. The success of a business is influenced by politics where the business is located. Improvement in the state has also been supported by business presence. One of the regulations on politics is Law number 2 of 2011 Articles 34 and 35 on financial resources and the maximum limit of contributions to political parties provides the impetus for conducting a study on political connections and company performance because one of the financial resources of political parties is donations from companies and/or business entities. The ethics of reciprocation that is still thick in Indonesia gives the view that donations made by companies to political parties are not free. Profit-oriented companies expect reciprocity, or the benefits derived from these donations. From the relationship between companies and politics, the term "politically connected company" emerged.

According to [1], a company is assumed to have a political connection if the controlling shareholder or president director functions as a member of parliament or government, the king or president of a country, or the leader or member of a political party. Companies that make political connections gain easier access to capital loans with extended credit limits when investor funds are not available [2]. Companies use political connections to gain profits for their business [3]. In the context of taxation, political connections can provide companies with access to better information about taxation regulations for future changes [4]. Political elites who unite business with politics in the coal mining sector, one of them is Aburizal Bakrie (former Chairman of the Golkar Party and Chair of the Golkar Party Board of Supervisors and former minister in the Government of Susilo Bambang Yudhoyono) with Bumi Resources and Prabowo Subianto (founder and Chairman of Gerindra Party) with the Nusantara business group.

The impact of political connections on tax avoidance 
through tax aggressiveness is largely unknown in the academic literature. Companies that carry out political connections, in general, often take tax aggressiveness. This is performed by the company so that it has a lower detection risk because politicians also provide protection to companies that are connected with it so that the risk of tax avoidance can be lower. Then the company can have better information about changes to tax regulations in the future. The perceived impact is also the low pressure from the capital market to conduct transparency and potentially reduce political costs related to tax planning activities through tax aggressiveness. Political connections are also beneficial for companies to get access to the central government [5].

Factors in the company's financial condition that affect tax avoidance, including focusing on the level of profitability of the company. Firm profitability with tax avoidance will have a positive relationship and if the company wants to avoid tax it must be more efficient in managing corporate profits so that it does not need to pay large amounts of tax [6]. An increase in profits will result in a higher tax to be paid, or it can be said that there is a possibility of avoidance tax. Research [7] examined profitability as an independent variable that is found to have a negative effect on tax avoidance.

Another factor affecting tax avoidance is capital intensity. Capital intensity ratio is the investment activity of a company that is associated with an investment in fixed assets and inventories. The ratio of capital intensity can show the efficiency of using assets to generate sales. Capital intensity can also be defined by how companies make sacrifices to spend on operating activities and funding of assets to obtain company profits. Research [8], stated that the composition of assets can have a clear effect on the effective tax rate, especially fixed assets that allow companies to cut the tax that comes from the depreciation expense of fixed assets each year. This shows that companies with large fixed assets tend to have low effective tax rates.

\section{LITERATURE REVIEW}

\subsection{Relationship Between Political Connection and Tax Avoidance}

Tax avoidance can be influenced by political connection [9]. Linked political connections of companies to tax avoidance and finding more or less the same research results [5]. Companies that have a political connection will get protection from the government, have easy access to get capital loans, the risk of low tax checks so that the company becomes more aggressive in doing tax planning which results in opaque financial transparency. Various kinds of special privileges can be obtained by companies with political connections even during a financial crisis, the company will easily get a bailout from the government. In addition, companies that have political connections with the government in power are proven to have significantly higher tax avoidance levels when compared to similar companies that have no political connections [5], [10], and [11].

\subsection{Relationship Between Profitability and Tax Avoidance}

High profits, of course, are good for a company. However, high profits mean that taxes must be paid high too. By avoiding taxes, companies can benefit in the form of cash savings. Research [12] showed that there was a significant relationship between tax avoidance and profitability. Similarly, research [8], [13] showed the same results. While research [14] found that the higher the profitability of companies will have an impact on the higher effective tax rate, which means the lower the tax avoidance performed. The higher the profitability of the company will cause a decrease in corporate tax avoidance because the higher the profitability, the better the company's performance so that the company is able to pay its tax obligations.

\subsection{Relationship Between Capital Intensity and Tax Avoidance}

Capital intensity is the amount of money invested to get an output of one dollar. The greater the capital used to produce the same unit; it can be said that the more intense the company's capital. In general, capital intensity is associated with the amount of capital owned by companies in the form of fixed assets, so that the ratio of fixed asset intensity is measured by what proportion of fixed assets of the total assets owned by the company [12] and [13] capital intensity affects tax avoidance because the fixed assets owned by the company can be depreciated and depreciation of assets can be charged as a deduction of profits for the company so that it will reduce the tax paid.

\section{RESEARCH METHODOLOGY}

The data used in this study were secondary data, in the form of financial statements of mining companies that have been audited and registered on the Indonesia Stock Exchange from 2014 to 2018

\subsection{Population and Sample}

The population in this study were all mining companies listed on the Indonesia Stock Exchange from 2014 to 2018. The sample selection method was purposive sampling, namely by categorizing companies based on certain criteria. Samples taken were mining companies registered 
in manufacturing companies listed on the Stock Exchange with the following criteria: Companies listed on the Stock Exchange from 2014 to 2018, companies that report their financial statements for three consecutive years during 2014 to 2018 so that they met the criteria data for the measurement of each variable. Companies that publish their financial statements in dollar units from 2014 to 2018 , because from the results of the study, most mining companies used dollar units.

\subsection{Analysis Technique}

The data analysis technique which is used is quantitative descriptive analysis. Data analysis in this study would use Multiple linear regression analysis techniques with the help of SPSS software, as for the series of tests to be carried out are: Multiple Linear Regression Analysis. Testing with a multiple linear regression model with the help of the SPSS program. Linear regression is used to detect several variables that are related to the variables being tested. Regression test knows the direction and magnitude of the influence between the independent variable and the dependent variable.

1. Coefficient of Determination (adjusted $R^{2}$ )

The coefficient of determination can be thought of as a percent. It is used to measure how far the ability of the model is to explain the variation of the dependent variable. The greater the coefficient of determination of a model, the greater the ability of independent variables in explaining the variation of the dependent variable.

2. Model Feasibility (F Statistic Test)

The F statistic test is a value you get when you run an ANOVA test or a regression analysis to find out if the means between two populations are significantly different. In this study criteria will be used if the probability is below 0.05 , then an alternative hypothesis is accepted which states that the regression model is feasible or good for use in research.

3. Individual Parameter Significance (T statistic test) $\mathrm{T}$ statistic test is used to determine if there is a significant difference between the means of two groups, which may be related in certain features. To find out whether the hypothesis is rejected or accepted, the criteria are used if the significance calculation value is below 0.05 , so the alternative hypothesis is accepted which states that individually independent variables affecting the dependent variable can be accepted.

Multiple linear regression analysis was used to test the influence of more than one independent variable on one dependent variable. So the regression model proposed is as follows:

$\mathrm{ETR}=\alpha+\beta 1 \mathrm{PC}+\beta 2 \mathrm{PRO}+\beta 3 \mathrm{CINT}+\epsilon \ldots$

Description

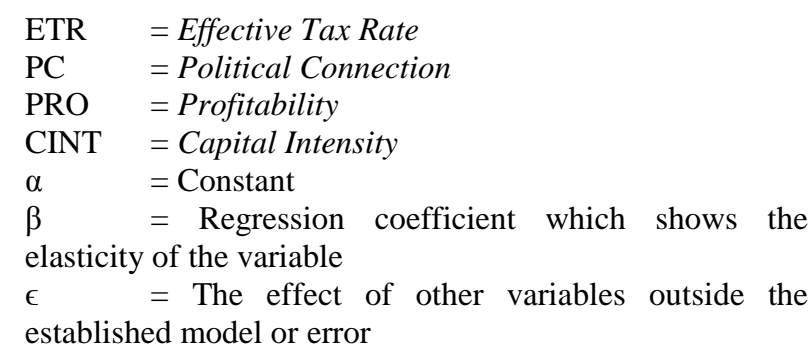

\subsection{Hypothesis}

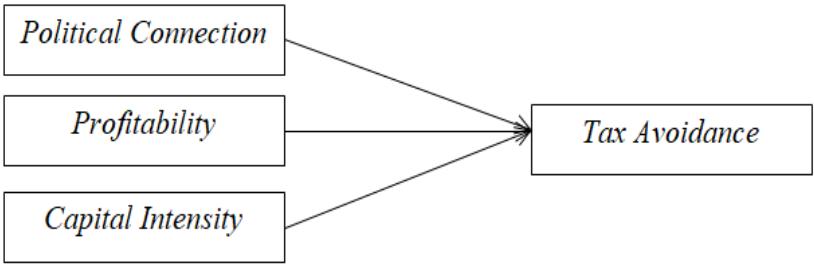

Figure 1 Research Framework (Source: Processed data, 2019)

Hypothesis

H1: Political connection had a positive influence on tax avoidance.

$\mathrm{H} 2$ : Profitability had negative influence on tax avoidance. H3: Capital Intensity had positive influence on tax avoidance

\section{RESULTS AND DISCUSSION}

\subsection{Normality Test}

The normality test aims to test whether, in the regression model, confounding or residual variables have a normal distribution so that the statistical test for the small sample size results remains valid. To test the normality of the data in this study the Kolmogorov-Smirnov (K-S) statistical test was performed by making the null hypothesis $(\mathrm{H} 0)$ for normally distributed data and the alternative hypothesis (Ha) for not normally distributed data. Table 1 is the One Sample Kolmogorov Smirnov Test Table.

Table 1 Kolmogorov Smirnov Test

\begin{tabular}{|c|c|c|c|c|c|}
\hline & & PC & ROA & $\mathrm{CI}$ & $\mathrm{AP}$ \\
\hline $\mathrm{N}$ & & 25 & 25 & 25 & 25 \\
\hline \multirow{2}{*}{ Normal Parameters ${ }^{2 b}$} & Mean & 22.64 & 9.64 & 70.68 & .40 \\
\hline & Std. Deviation & 10.583 & 11.478 & 11.014 & .500 \\
\hline Most Extreme & Absolute & .079 & .437 & .083 & .388 \\
\hline \multirow[t]{2}{*}{ Differences } & Positive & .079 & .437 & .057 & .388 \\
\hline & Negative & -.065 & -.253 & -.083 & -.285 \\
\hline Test Statistic & & .079 & .437 & .083 & .388 \\
\hline Asymp. Sig. (2-tailed) & & $.200^{\circ, \mathrm{d}}$ & $.000^{\mathrm{c}}$ & $.200^{\mathrm{c}, \mathrm{d}}$ & $.000^{\circ}$ \\
\hline
\end{tabular}


Based on Table 1, the results of normality test calculations used the One-Sample KolmogorovSmirnov Test. Residuals are declared normally distributed if the significance value of KolmogorovSmirnov Test (Statistic Test) > 0.05. So it can be concluded that the residual regression model had a normal distribution.

\section{2. $F-T E S T$}

F statistical test was conducted to find out whether the regression equation model in the study was fit or not fit. The results of the regression model test (F test) can be seen in Table 2:

Table 2 F statistical test

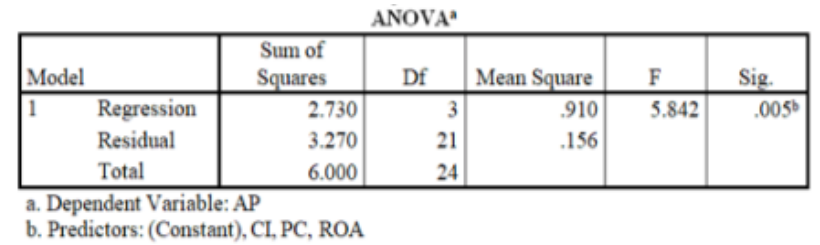

Based on Table 2. it can be seen that the calculated $F$ value of 5.842 with a significant level of $0.0005<0.05$, it can be concluded that the regression fit model can be used to determine the influence of Political Connection, Return On Assets and Capital Intensity together influenced the Tax Avoidance variable.

\subsection{Coefficient of determination (R2)}

The coefficient of determination (R2) is used to measure how much the ability of the model (the influence of independent variables) in explaining the variation of the dependent variable. The results of the $\mathrm{R} 2$ test can be in Table 3 .

Table 3 The coefficient of determination (R2)

\begin{tabular}{|l|c|r|r|r|}
\hline Model & $\mathrm{R}$ & R Square & $\begin{array}{c}\text { Adjusted R } \\
\text { Square }\end{array}$ & $\begin{array}{c}\text { Std. Error of } \\
\text { the Estimate }\end{array}$ \\
\hline 1 & $.674^{\mathrm{a}}$ & .455 & .377 & .395 \\
\hline
\end{tabular}

a. Predictors: (Constant), CI, PC, ROA

Based on Table 3, R2 test results the coefficient of determination R2 is known that the Adjusted R Square value of 0.455 or $45.50 \%$. This shows that $45.50 \%$, which means Political Connection, Return on Assets and Capital Intensity influenced Tax Avoidance of $45.50 \%$ while the remaining $54.50 \%$ was explained by other variables outside the independent variable.

\subsection{T-test}

The statistical T-test aims to show how far the influence of one (each) Independent variable individually in explaining the variation of the dependent variable. The results of the $t$ test is shown in Table 4 :

Table 4 Statistical T- Test

\begin{tabular}{|c|c|c|c|c|c|c|}
\hline \multicolumn{7}{|c|}{ Coefficients ${ }^{2}$} \\
\hline & & \multicolumn{2}{|c|}{ Unstandardized Coefficients } & $\begin{array}{l}\text { Standardized } \\
\text { Coefficients }\end{array}$ & \multirow[b]{2}{*}{$t$} & \multirow[b]{2}{*}{ Sig. } \\
\hline \multicolumn{2}{|c|}{ Model } & B & Std. Error & Beta & & \\
\hline \multirow[t]{4}{*}{1} & (Constant) & 2.086 & .574 & & 3.633 & .002 \\
\hline & PC & .017 & .008 & .368 & 2.115 & .047 \\
\hline & ROA & -.027 & .008 & -.621 & -3.416 & .003 \\
\hline & $\mathrm{CI}$ & -.026 & .008 & -.567 & -3.309 & .003 \\
\hline
\end{tabular}

\subsection{First Hypothesis Test}

The first hypothesis testing was conducted on the influence of Political Connection on Tax Avoidance. Based on Table 4, the Political Connection variable had $\mathrm{t}$ calculated value of 2.115 and a significant level of 0.047, which means that the significant level of Political Connection variable was smaller than 0.05 . So that the Political Connection variable influenced Tax Avoidance.

\subsection{Second Hypothesis Test}

The second hypothesis testing was conducted on the influence of Return On Assets on Tax Avoidance. Based on Table 4, the Return On Asset variable had a t-value of 3.416 and a significant level of 0.003 , which means that the significant level of the Return On Asset variable was smaller than 0.05. So, the Return On Asset variable influenced the Tax Avoidance.

\subsection{Third Hypothesis Test}

The third hypothesis testing was conducted on the influence of Capital Intensity on Tax Avoidance. Based on Table 4 , it can be seen that the Capital Intensity variable had t-value of -3.309 and a significant level of 0.003 , which means that the significant level of the Capital Intensity variable was smaller than 0.05 . So that the Capital Intensity variable influenced Tax Avoidance.

\subsection{Discussion}

Illicit financial flows in the Indonesian coal mining industry which indicates tax avoidance. In addition, this is a sign that the taxation in the coal sector is not okay. This phenomenon raises a big question considering that there 
are already many regulations that regulate strictly starting from operating permits to the distribution of profits from coal sales. In addition to the problem of overlapping regulations and the existence of legal loopholes that can be exploited by coal businesses to avoid tax. The low tax revenue from the coal sector is also caused by the weak capacity of the tax authority and tax authorities in examining taxpayers so that various allegations of tax avoidance or tax disputes submitted by the tax authorities always lose in the tax court. It should also be noted that among taxpayers who report their tax returns there is the potential of not reporting according to the facts. Not a few of them reported their tax returns correctly but were the result of tax avoidance and tax savings such as aggressive tax planning.

Based on the above test, the Political connection influenced the practice of tax avoidance. This shows that the existence of political connections established in a company can influence the practice of tax avoidance in a company. This means that existing regulations and controls in Indonesia have not been able to "negate" the practices of collusion that might arise in connection with the existence of special relationships or political connections that exist in a company going public. This study is in line with research conducted by [5] that linked a company's political connection to tax avoidance and stated that political connections had a significant relationship to tax avoidance.

This study also showed that profitability, in this case, ROA influenced tax avoidance. The company's performance represented by ROA influenced the practice of tax avoidance. ROA is an indicator of a company's ability to generate profits so ROA is an important factor in the imposition of income tax for companies. This is because the conservatism level of companies that go public is quite high. Conservatism itself is a principle of prudence in preparing financial statements, where companies that implement this tend to avoid tax. The level of profitability of the company negatively influenced the effective tax rate because the more efficient the company is, the company will pay less tax so that the company's effective tax rate becomes lower. This study is in line with [12] showed that there was a significant relationship between profitability and tax avoidance.

This study also shows that Capital Intensity influenced tax avoidance. This means that companies that tend to invest in fixed assets will affect the level of tax aggressiveness in coal companies by utilizing depreciation to reduce their tax payments. The company's fixed assets allow the company to reduce its taxes as a result of depreciation arising from fixed assets each year. Because the depreciation expense affects as a deduction from the tax. This research is in line with [12] and [13] showed that there was a significant relationship between capital intensity and tax avoidance.

\section{CONCLUSION}

The results of the study stated that, the Political connection influenced the practice of tax avoidance. This shows that the existence of political connections established in a company can influence the practice of tax avoidance in a company. Return on Assets influenced tax avoidance. This is because the conservatism level of companies that go public is quite high. Conservatism itself is a principle of prudence in preparing financial statements, where companies that implement this tend to avoid tax. Capital Intensity influenced tax avoidance. This means that companies that tend to invest in fixed assets will affect the level of tax aggressiveness in manufacturing companies in the consumer goods industry by utilizing depreciation to reduce their tax payments.

Based on the above limitations, the next research uses market ratios to measure company performance. The agreed market ratio in this case is the ratio issued from the company's stock price. Some ratios that can be used to measure market value, among others: price earning ratio (PER), market- to- book ratio, Tobin's Q, and price/ cash flow ratio

\section{REFERENCES}

[1] Faccio, M. (2010). Differences between Politically Connected and Nonconnected Firms: A Cross- Country Analysis. Financial Management, 39(3), 905-928

[2] Houston, J. F., Jiang, L., Lin, C., \& Ma, Y. (2014). Political Connections and the Cost of Bank Loans. Journal of Accounting Research, 52(1), 193-243.

[3] Brown, J. L., Drake, K., \& Wellman, L. (2015). The Benefits of a Relational Approach to Corporate Political Activity: Evidence from Political Contributions to Tax Policymakers. The Journal of the American Taxation Association, $37(1), 69-102$.

[4] Milyo, J., Primo, D., \& Groseclose, T. (2017). Corporate PAC Campaign Contributions in Perspective. Business and Politics, 2(1), 75-88.

[5] Kim, C., \& Zhang, L. (2016). Corporate Political Connections and Tax Aggressiveness. Contemporary Accounting. University of HongKong. Research, 33(1), 78-114

[6] Rizal, Muhammad. 2016. Why Company Does Tax Avoidance? Evidence from a Manufacturing Company in Indonesia Stock Exchange. International Journal of Business and Management Invention, 5(5)

[7] Hanny, R \& Ninadari, N. (2018). Tax Avoidance Practice: Political Connection, Firm Characteristics and Audit Quality Test at Banking Industry in Indonesia. International Journal of Business 
Management and Economic Research (IJBMER), Vol 9(3),2018, 1296-1303. ISSN:2229- 6247.

[8] Delgado, Francisco J., Elena FernandezRodriguez, dan Antonio Martinez-Arias. 2014. Effective Tax Rates in Corporate Taxation: A Quantile Regression for the EU. Engineering Economics, 25(5).

[9] Li, C., Wang, Y., Wu, L., \& Xiao, J. Z. (2016). Political Connections and Tax-Induced Earnings Management: Evidence from China. The European Journal of Finance, 22(4-6), 413-431.

[10] Leuz, C., \& Oberholzer-Gee, F. (2013). Political Relationships, Global Financing, And Corporate Transparency: Evidence From Indonesia. Journal Of Financial Economics, 81(2), 411-439.

[11] Christensen, D. M., Dhaliwal, D. S., Boivie, S., \& Graffin, S. D. (2014). Top Management Conservatism And Corporate Risk Strategies: Evidence From Managers' Personal Political Orientation And Corporate Tax Avoidance. Strategic Management Journal.

[12] Richardson, Grant, Bei Wang, dan Xinmin Zhang. 2016. Ownership Structure and Corporate Tax Avoidance: Evidence from Publicly Listed Private Firms in China. Journal of Contemporary Accounting \& Economics, 12(2).

[13] Kraft, Anastasia. 2014. What Really Affects German Firm's Effective Tax Rate?. International Journal of Financial Research, 5(3).

[14] Zarai, MohamedAli. 2013. Corporate Tax Planning and Debt Endogeneity: Case of American Firms. International Journalof Business and Commerce, 3(3) 